\title{
Inhibition of fibroblast proliferation and collagen synthesis by capsular material from Actinobacillus actinomycetemcomitans
}

\author{
S. KAMIN, W. HARVEY, M. WILSON* and A. SCUTT
}

Departments of Oral and Maxillo-Facial Surgery, and *Clinical Pathology and Immunology, Institute of Dental Surgery, Eastman Dental Hospital, 256 Grays Inn Road, London WC1X 8LD

Summary. Cytotoxic effects of bacteria found in dental plaque are usually attributed to lipopolysaccharides (LPS) or ill-defined toxins. Many bacteria implicated in periodontal disease produce surface exopolymers (capsules) recently shown to stimulate bone resorption. Capsular material and LPS extracted from Actinobacillus (Haemophilus) actinomycetemcomitans were purified and examined for their effects on cultures of human gingival fibroblasts. DNA and collagen synthesis were significantly inhibited by capsular material $(0.1-50 \mu \mathrm{g} / \mathrm{ml})$. LPS caused only modest inhibition of DNA synthesis at 10 and $50 \mu \mathrm{g} / \mathrm{ml}$, and had no effect on collagen synthesis. Release of lactate dehydrogenase from fibroblasts was not increased by LPS nor by capsular material, showing that the inhibitory effects were not due to cell death. Capsular material, but not LPS, caused a pronounced increase in cell size; a doubling of the nuclear area occurred within $72 \mathrm{~h}$ exposure. These results indicate that the capsule of $A$. actinomycetemcomitans may play an active role in the tissue destruction characterising inflammatory periodontal disease.

\section{Introduction}

The clinical manifestations of periodontitis result from the effects of bacteria on host tissues. Bacterial products can exert a direct effect or can act indirectly by inducing inflammatory changes. In localised juvenile periodontitis (LJP) there is marked tissue destruction, especially bone resorption, but minimal inflammation (Baer, 1971; Hørmand and Frandsen, 1979), and the direct cytotoxic effects of bacterial products appear to play an important role. Such effects on the fibroblasts of the periodontium result in a decrease in cell numbers and a net loss of collagen (Page and Schroeder, 1976).

Actinobacillus (Haemophilus) actinomycetemcomitans has been implicated in LJP (Slots, 1979; Slots et al., 1980; Zambon et al., 1983) and attempts have been made recently to examine the mechanisms by which it damages periodontal tissues. In vitro soluble extracts of $A$. actinomycetemcomitans have been shown to inhibit the proliferation of several cell types including lymphocytes (Shenker et al., 1982a), fibroblasts (Shenker et al., 1982 b; Stevens et al., 1983), epithelial cells (Kamen, 1983), and endothelial cells (Taichman et al., 1984). This inhibitory activity has been observed in both

Received 11 Feb. 1986; accepted 27 Feb. 1986. leukotoxic and non-leukotoxic strains (Taichman et al., 1982), and is therefore not attributable to a leukotoxin.

Lipopolysaccharide (LPS) is generally regarded as the component responsible for the cytotoxicity to fibroblasts demonstrated in plaque extracts from the teeth of patients with periodontal disease and in bacterial sonicates (Hatfield and Baumhammers 1971; Aleo et al., 1974). However, there have been no such studies with purified LPS preparations in which a contribution from other bacterial factors has been eliminated. This is important because components other than LPS, e.g., peptidoglycans, are known to affect connective tissue cells (Lensgraf et al., 1979) and recently we reported that capsular material (CM) purified from $A$. actinomycetemcomitans stimulates bone resorption in vitro at concentrations as low as $1 \mathrm{mg} / \mathrm{ml}$ (Wilson et al., 1985). Therefore we decided to examine and compare the effects of LPS and CM from A. actinomycetemcomitans on human gingival fibroblasts in vitro.

\section{Materials and methods}

\section{Bacterial cultivation}

A. actinomycetemcomitans NCTC 9710 was kindly 
supplied by Dr P. Marsh (CAMR, PHLS, Porton Down). The organism was grown in batch cultures at $37^{\circ} \mathrm{C}$ in anaerobic conditions in the following medium: Tryptone $10 \mathrm{~g}$, glucose $2 \mathrm{~g}$, yeast extract $5 \mathrm{~g}, \mathrm{NaHCO}_{3}$ $5 \mathrm{~g}$, dithiothreitol $50 \mathrm{mg}$ and biotin $1 \mathrm{mg}$ in $1 \mathrm{~L}$ of distilled water. After incubation for $24 \mathrm{~h}$ a smear of the culture was stained by Gram's method to check for contamination and then centrifuged at $30000 \mathrm{~g}$ for $30 \mathrm{~min}$ at $40^{\circ} \mathrm{C}$. The harvested cells were washed with saline, recentrifuged and then lyophilised.

\section{Preparation of capsular material}

Capsular material was extracted from $1 \cdot 1 \mathrm{~g}$ of lyophilised bacteria (Wilson et al., 1985). Saline $(100 \mathrm{ml})$ was added to the cells and the suspension was gently agitated for $1 \mathrm{~h}$ at $40^{\circ} \mathrm{C}$, centrifuged at $30000 \mathrm{~g}$ for $45 \mathrm{~min}$ and the supernate removed. This saline extraction was repeated twice and then acetone at $-20^{\circ} \mathrm{C}$ was added to the supernate. The precipitate was centrifuged as above and the pellets redissolved, dialysed against distilled water and lyophilised. This crude CM was then purified by gel filtration and ion-exchange chromatography.

\section{Preparation of LPS}

LPS was extracted by the hot phenol-water method of Westphal and Jann (1965) after the removal of capsular material from the lyophilised cells. This crude LPS preparation was purified by treatment with DNAase, RNAase and Pronase and then ultracentrifugation (Kiley and Holt, 1980). The LPS and CM preparations were lyophilised and, for experimental use, dissolved directly in tissue culture medium.

\section{Fibroblast cultures}

Human gingival fibroblasts were grown from explants obtained during minor oral surgical procedures. The cells were grown in Eagles' MEM (Gibco-Europe), supplemented with fetal calf serum (FCS) 10\%, 2mM L-glutamine, $\mathrm{NaHCO}_{3} 2.25 \mathrm{~g} / \mathrm{L}$, penicillin and streptomycin (each $100 \mathrm{U} / \mathrm{ml}$ ) and incubated at $37 \mathrm{C}^{\circ} \mathrm{CO}_{2} 5 \%$ in air. Cells were subcultured at weekly intervals with trypsin $0.25 \%$ and used for experiments between passages 6 and 12.

\section{Incorporation of ${ }^{3} \mathrm{H}$-thymidine}

Fibroblast suspensions were seeded into 96-well culture plates (Microtitre, Linbro) at concentrations of 15000 cells/well in $100 \mu \mathrm{l}$ of MEM with FCS $10 \%$ and left overnight to attach. The following day culture medium was replaced by MEM with FCS $10 \%$ containing purified LPS or CM at concentrations of $0 \cdot 1-50 \mu \mathrm{g} /$ $\mathrm{ml}$, in groups of six wells per concentration. Control cultures received only fresh medium. Cells were further incubated for $24 \mathrm{~h}$ and $0.5 \mu \mathrm{Ci}$ of $5-{ }^{3} \mathrm{H}$-thymidine (specific activity $20 \mathrm{Ci} / \mathrm{mmol}$; Amersham International) was introduced into each well $4 \mathrm{~h}$ before termination of the cultures. Trichloroacetic acid-insoluble material in each cell layer was dissolved in $0.4 \mathrm{M} \mathrm{NaOH}$ and radioactivity measured in $3.0 \mathrm{ml}$ of scintillant (Unisolve I, Koch Light) by scintillation spectrometry (Rackbeta; LKB, Sweden) with external standardisation. Radioactivity was expressed as disintegrations/min (dpm)/well.

\section{Collagen synthesis}

The rate of collagen synthesis was estimated by the incorporation of ${ }^{3} \mathrm{H}$-proline into pepsin-resistant native collagen during a 24-h period (Webster and Harvey, 1979). $5-{ }^{3} \mathrm{H}$-proline $(0 \cdot 2 \mu \mathrm{Ci} ; 2 \cdot 3 \mathrm{Ci} / \mathrm{mmol}$; Amersham International) was added to each well in $200 \mu$ l of MEM plus FCS $10 \%$ containing $\beta$-aminopropionitrile fumarate and L-ascorbic acid ( $50 \mu \mathrm{g} / \mathrm{ml}$ of each). On termination, the cell layer and culture medium together were extracted with pepsin $0.5 \mathrm{mg} / \mathrm{ml}$ in $0.5 \mathrm{M}$ acetic acid for $16 \mathrm{~h}$ at $4 \mathrm{C}$, and the ${ }^{3} \mathrm{H}$-labelled collagen precipitated twice with $0.8 \mathrm{M} \mathrm{NaCl}$; the carrier was $100 \mu \mathrm{g}$ of acidsoluble rat skin collagen. The final collagen pellet was dissolved in $250 \mu \mathrm{l} 0.5 \mathrm{M}$ acetic acid and radioactivity was measured as described above.

\section{Lactate dehydrogenase ( $\mathrm{LDH}$ )}

The release of LDH into culture medium was used as an index of cell lysis. Fibroblasts were seeded at a concentration of $15000 \mathrm{cells} / \mathrm{well}$ and left overnight to attach. LPS or CM $(50 \mu \mathrm{g} / \mathrm{ml})$ was dissolved in MEM supplemented with $0.5 \%$ serum substitute Ultroser G (LKB, Sweden) to eliminate the contribution of LDH from FCS. After incubation for $72 \mathrm{~h}$, the culture medium was removed and 50- $\mu$ l portions were retained for $\mathrm{LDH}$ measurement. Assay buffer $(50 \mathrm{~mm}$ Tris- $\mathrm{HCl}, 0.15 \mathrm{M}$ $\mathrm{NaCl}, p \mathrm{H}$ 7.5) $100 \mu \mathrm{l}$ was added to each well and the cells extracted into this by freezing and thawing three times and $50 \mu \mathrm{l}$ of the resulting extracts were then used to measure LDH activity in the cell layer. LDH was measured by reduction of pyruvate in the presence of NADH during a 5-h incubation period for culture supernates and $30 \mathrm{~min}$ for cell extracts. The absorbance of the hydrazone derivative of pyruvate was measured at $450 \mathrm{~nm}$ (Wroblewski and Gregory, 1961). Cell lysis was calculated as the ratio of medium $\mathrm{LDH}$ to total $\mathrm{LDH}$, expressed as a percentage.

\section{Nuclear area}

Fibroblasts were seeded at a concentration of 15000 cells/well and left overnight to attach. LPS or CM $(50 \mu \mathrm{g} /$ $\mathrm{ml}$ ) was dissolved in MEM plus FCS $10 \%$ and $100 \mu \mathrm{l}$ was added to each well (six wells/group). The plates were examined by phase contrast microscopy every $24 \mathrm{~h}$, and after incubation for $72 \mathrm{~h}$ the cells were fixed with methanol and stained by Giemsa's method. The bottom of each well was removed and mounted on a glass slide. The nuclear area of 70 cells in each preparation was measured 


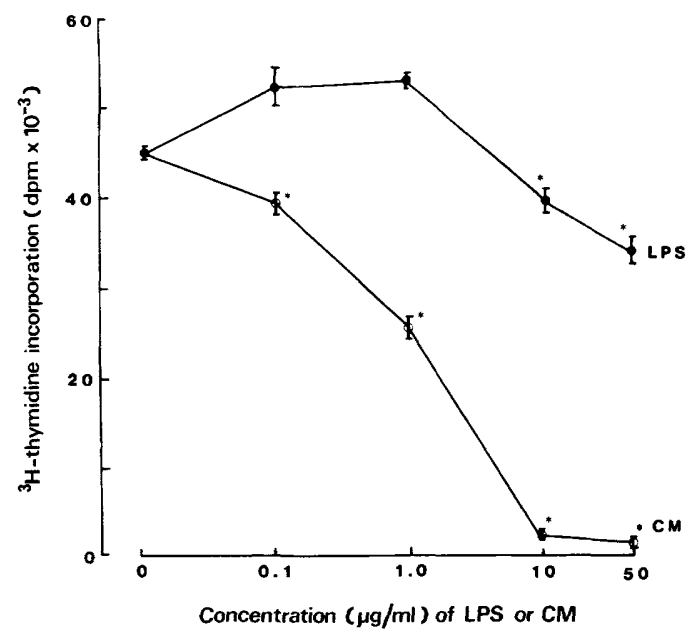

Fig. 1. Effect of LPS and CM on DNA synthesis in human gingival fibroblasts; ${ }^{*} \mathrm{p}<0.05$.

by planimetry of the projected images with a computer image analysis system (Kontron 64, W. Germany).

\section{Results}

CM caused a concentration-dependent inhibition of ${ }^{3} \mathrm{H}$-thymidine incorporation which was significant at a concentration of $0 \cdot 1 \mu \mathrm{g} / \mathrm{ml}$ and above (fig. 1). LPS caused less inhibition, significant only at 10 and $50 \mu \mathrm{g} / \mathrm{ml}$. CM caused a profound inhibition of collagen synthesis; $75 \%$ reduction occurred at $50 \mu \mathrm{g} / \mathrm{ml}$ (fig 2). In contrast, LPS did not significantly alter the rate of collagen synthesis at any of the concentrations tested.

LDH release during 3 days was approximately

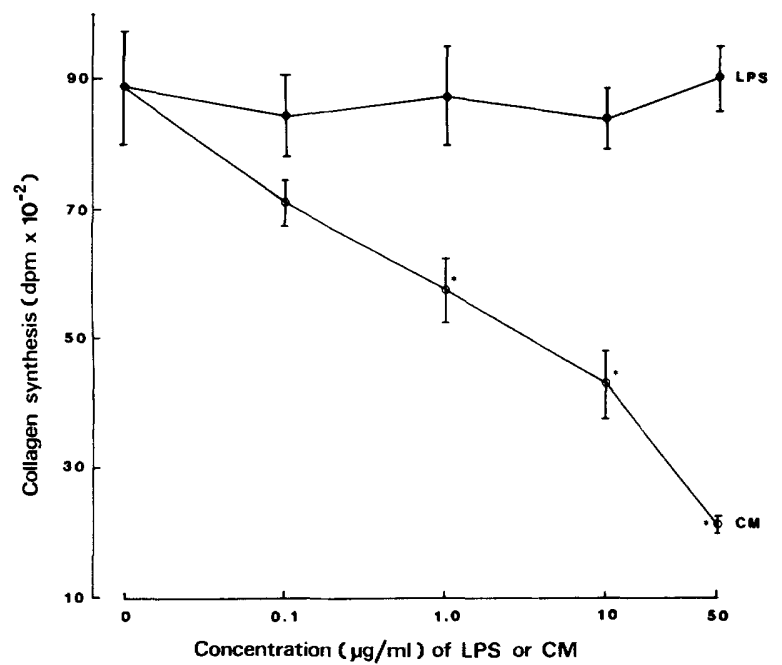

Fig. 2. Effect of LPS and CM on collagen synthesis by human gingival fibroblasts; ${ }^{*} \mathrm{p}<0.05$.
Table I. Effect of various concentrations of capsular material (CM) and lipopolysaccharide (LPS) on the release of lactate dehydrogenase (LDH) by human gingival fibroblasts

\begin{tabular}{lcc}
\hline Component & $\begin{array}{c}\text { Concentration } \\
(\mu \mathrm{g} / \mathrm{ml})\end{array}$ & $\begin{array}{c}\text { LDH release } \\
(\% \pm \mathrm{SD})\end{array}$ \\
\hline Capsular material & $0 \cdot 1$ & $5 \cdot 28 \pm 0.53$ \\
& $1 \cdot 0$ & $5 \cdot 16 \pm 0.50$ \\
& $10 \cdot 0$ & $5 \cdot 08 \pm 0 \cdot 37$ \\
Lipopolysaccharide & $50 \cdot 0$ & $5 \cdot 45 \pm 0.67$ \\
& $0 \cdot 1$ & $5 \cdot 75 \pm 0.62$ \\
& $1 \cdot 0$ & $5 \cdot 30 \pm 0.54$ \\
Control & $10 \cdot 0$ & $4.97 \pm 0.71$ \\
& $50 \cdot 0$ & $5 \cdot 60 \pm 0.53$ \\
& $\ldots$ & $5.04 \pm 0.60$ \\
\hline
\end{tabular}

$5 \%$ in control cultures and did not vary significantly in cultures containing CM or LPS at concentrations up to $50 \mu \mathrm{g} / \mathrm{ml}$ (table I). Microscopic examination of the fibroblasts confirmed that cell lysis had not occurred. However, CM-treated cells exhibited gross morphological changes; there was a progressive increase in cytoplasmic and nuclear area, detectable after $24 \mathrm{~h}$ and clearly visible after $72 \mathrm{~h}$ (fig. 3B). This was confirmed by measurement of the nuclear area which, in the CM-treated cells, was twice that of the control cells (table II). The nuclear area of LPS-treated cells was not significantly different from controls.

\section{Discussion}

These experiments showed that capsular material from $A$. actinomycetemcomitans is a potent inhibitor of gingival fibroblast proliferation, whereas LPS from the same organism had little effect. The lack of effect on LDH release, even at $50 \mu \mathrm{g} / \mathrm{ml}$, indicated that the reduction of ${ }^{3} \mathrm{H}$-thymidine incorporation was due to inhibition of cell proliferation rather than to cell death. It is likely, therefore, that $\mathrm{CM}$ is responsible for the inhibitory activity found in crude extracts of $A$. actinomycetemcomitans. This is supported by the observations of Shenker et al. (1982b) and Stevens et al. (1983) who concluded that the fibroblast inhibitory factor was neither endotoxin nor a leukotoxin. Stevens et al. (1983) found that similar inhibitory activity present in a phosphate-buffer extract of $A$. actinomycetemcomitans was equal to that found in sonic extracts of the cultures, suggesting that looselybound surface components may have been responsible for the activity in the sonicates. Earlier demonstrations of cytotoxicity to fibroblasts by LPS 


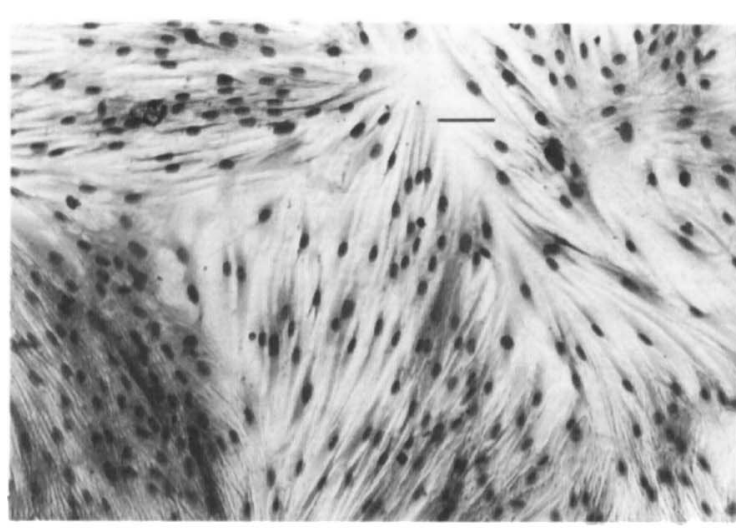

a

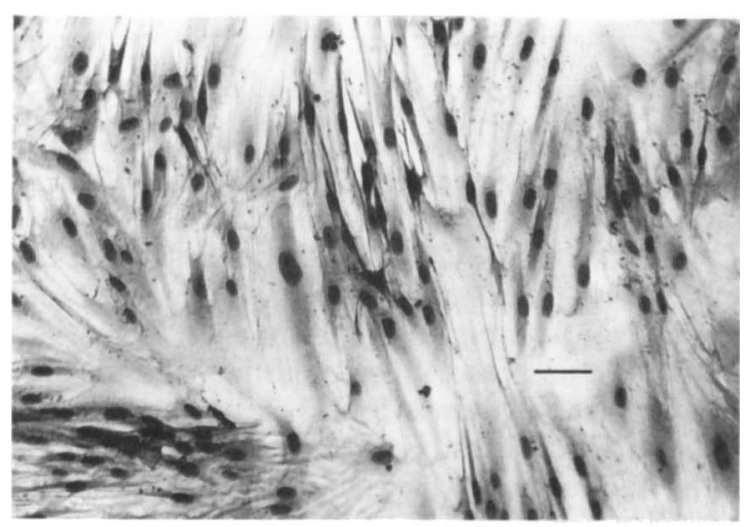

b

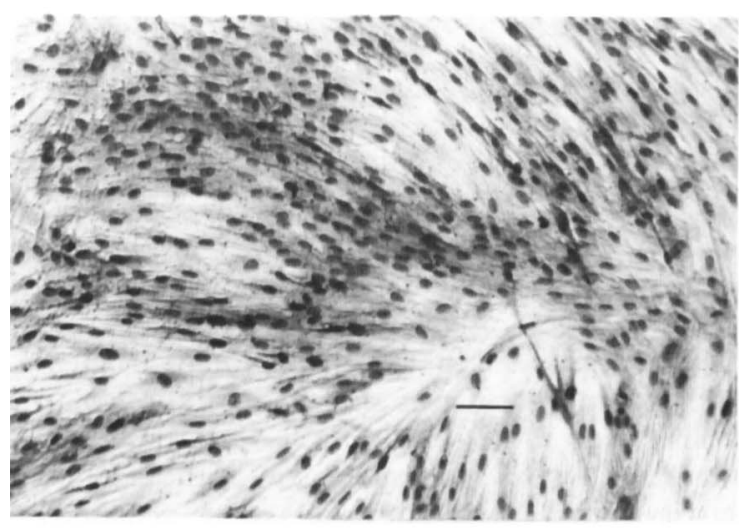

C

Fig. 3. Human gingival fibroblasts incubated for $72 \mathrm{~h}$ in: (a) MEM + FCS 10\% (control); (b) CM $50 \mu \mathrm{g} / \mathrm{ml}$; and (c) LPS $50 \mu \mathrm{g} / \mathrm{ml}$. Giemsa stain; bar $=100 \mu \mathrm{m}$.

\section{REFERENCES}

Aleo J J. De Renzis F A, Farber P A, Varboncoeur A P 1974 The presence and biologic activity of cementum-bound endotoxin. Journal of Periodontology 45:672-675.
Table II. Nuclear area of human gingival fibroblasts after exposure to bacterial components $(50 \mu \mathrm{g} / \mathrm{ml})$ for $72 \mathrm{~h}$

\begin{tabular}{lc}
\hline Cells & $\begin{array}{c}\text { Mean nuclear area } \\
\left(\mu \mathrm{m}^{2} \pm \mathrm{SD}\right)\end{array}$ \\
\hline Control & $167 \cdot 66 \pm 31 \cdot 27$ \\
CM-treated & $355 \cdot 17 \pm 94 \cdot 08^{*}$ \\
LPS-treated & $165 \cdot 69 \pm 31 \cdot 08$ \\
\hline
\end{tabular}

* Significantly different from control (Student's $t$ test, $\mathrm{p}<0.01$ ).

(Bergman and Nilsson, 1963; Alec et al., 1974) used Escherichia coli as a source of LPS and the purification methods may not have excluded the presence of other bacterial components, including CM. In the present study, more rigorous purification procedures minimised possible contamination of the LPS. The inhibition of collagen synthesis by CM was in marked contrast to the lack of effect by LPS. Aleo (1980) found that LPS from E. coli stimulated collagen synthesis in a mouse fibroblast line, but the differences between the type of fibroblasts and the source and purity of the LPS preparations in this study and our own make direct comparison difficult. However, the lack of inhibition of collagen synthesis by LPS in vitro in both studies suggests that collagen loss in periodontal disease is not due to inhibition of its synthesis by LPS. The present studies have shown that $\mathrm{CM}$, rather than LPS, may be the principal factor in bacterial sonicates and plaque extracts that inhibit fibroblast growth and collagen synthesis in vitro.

Histological examination of gingival tissue in the early stages of periodontitis has revealed a threefold increase in fibroblast size, attributed to the action of lymphocyte products (Schroeder et al., 1973). However, our finding that CM caused fibroblast enlargement in vitro suggests that bacterial components may contribute to this effect. Although the enlargement in vivo is thought to reflect cell morbidity (Page and Schroeder, 1977), CM produced this effect without cell lysis. This raises the possibility that $\mathrm{CM}$ may be responsible for some of the early pathological changes in periodontitis in addition to its potential for stimulating the bone resorption characteristic of the later stages of the disease.

Aleo J J 1980. Stimulation of macromolecular synthesis by endotoxin-treated 3T6 fibroblasts. Experientia 36:546-547.

Baer P N 1971 The case for peridontosis as a clinical entity. Journal of Periodontology 42:516-520.

Bergman S, Nilsson S B 1963 Effect of endotoxin on embryonal 
chick fibroblasts cultured in monolayer. Acta Pathologica et Microbiologica Scandinavica 59:161-164.

Hatfield C G, Baumhammers A. 1971 Cytotoxic effects of periodontally involved surfaces of human teeth. Archives of Oral Biology 16:465-468.

Hørmand J, Frandsen A 1979 Juvenine periodontitis. Localisation of bone loss in relation to age, sex and teeth. Journal of Clinical Periodontology 6:407-416.

Kamen P R 1983 Inhibition of keratinocyte proliferation by extracts of Actinobacillus actinomycetemcomitans. Infection and Immunity 42:1191-1194.

Kiley P, Holt S C 1980 Characterization of the lipopolysaccharide from Actinobacillus actinomycetemcomitans Y4 and N27. Infection and Immunity 30:862-873.

Lensgraf E J, Greenblatt J J, Bawden J W 1979 Effect of group A streptococcal peptidoglycan and group A streptococcal cell wall on bone in tissue culture. Archives of Oral Biology 24:495-498.

Page R C, Schroeder H E 1976 Pathogenesis of inflammatory periodontal disease. A summary of current work. Laboratory Investigation 34:235-249.

Page R C, Schroeder H E 1977 Structure and pathogenesis. In: Schluger $\mathrm{S}$ et al. (eds) Periodontal disease: basic phenomena, clinical management and occlusal and restorative interrelationships Lea and Fabiger, Philadelphia, p 168.

Schroeder H E, Munzel-Pedrazzoli S, Page R C 1973 Correlated morphometric and biochemical analysis of gingival tissue in early chronic gingivitis in man. Archives of Oral Biology 18:899 923 .

Shenker B J, McArthur W P, Tsai C C 1982a Immune suppression induced by Actinobacillus actinomycetemcomitans. 1 . Effects on human peripheral blood lymphocyte response to mitogens and antigens. Journal of Immunology 128:148154.

Shenker B J, Kushner M E, Tsai C C $1982 b$ Inhibition of fibroblast proliferation by Actinobacillus actinomycetemcomitans. Infection and Immunity 38:985-992.

Slots J 1979 Subgingival microflora and periodontal disease. Journal of Clinical Periodontology 6:351-382.
Slots J, Reynolds HS, Genco RJ 1980 Actinobacillus actinomycetemcomitans in human periodontal disease: a cross-sectional microbiological investigation. Infection and Immunity 29:1013-1020.

Stevens R H, Gatewood C, Hammond B F 1983 Cytotoxicity of the bacterium Actinobacillus actinomycetemcomitans extracts in human gingival fibroblasts. Archives of Oral Biology 28:981-987.

Taichman N S et al. 1982 Leukocidal mechanisms of Actinobacillus actinomycetemcomitans. In: Geneo R J, Mergenhagen $\mathrm{S} \mathrm{E}$ (eds) Host-parasite interactions in periodontal diseases. American Society for Microbiology, Washington, D.C. pp 261-269.

Taichman, N S, Klass J E, Shenker B J, Macarak E J, Boehringer H, Tsai C C 1984 Suspected periodontopathic organisms alter in vitro proliferation of endothelial cells. Journal of Periodontal Research 19:583-586.

Webster D F, Harvey W 1979 A quantitative assay for collagen synthesis in microwell fibroblast cultures. Analytical Biochemistry 96:220-224.

Westphal O, Jann K 1965 Bacterial lipopolysaccharides. Extraction with phenol-water and further applications of the procedure. Methods of Carbohydrate Chemistry 5:83-91.

Wilson M, Kamin S and Harvey W 1985 Bone-resorbing activity of purified capsular material from Actinobacillus actinomycetemcomitans. Journal of Periodontal Research 20:484 491.

Wroblewski F, Gregory K F 1961 Lactic dehydrogenase isozymes and their distribution in normal tissues and plasma and in disease states. Annals of the New York Academy of Sciences 94:912-932.

Zambon J J, Christersson L A, Slots J 1983 Actinobacillus actinomycetemcomitans in human periodontal disease: prevalence in patient groups and distribution of biotypes and serotypes within families. Journal of Periodontology 54: 707-711. 